\title{
O PENSAMENTO HELENÍSTICO NOS LIVROS DIDÁTICOS DE FILOSOFIA PARA O ENSINO MÉDIO: UMA ANÁLISE DAS OBRAS DISPONIBILIZADAS PELO PNLD
}

\author{
THE HELENISTIC THINKING IN THE DIDACTIC BOOKS OF \\ PHILOSOPHY FOR HIGH SCHOOL: AN ANALYSIS OF BOOKS \\ PROVIDED BY PNLD
}

\author{
Antônio Alex Pereira de Sousa ${ }^{1}$ \\ José Carlos Silva de Almeida ${ }^{2}$
}

Recebido em: 05/2018

Aprovado em: 07/2018

\begin{abstract}
Resumo: o artigo apresenta uma análise comparativa dos livros de filosofia do Ensino médio disponibilizados pelo Programa Nacional do Livro Didático (PNLD) 2015 à rede pública de educação brasileira, especificamente os temas e questões em torno dos filósofos helenísticos. Para isso, observamos os conceitos e o uso de fragmentos de textos filosóficos que colaborem para a compreensão das temáticas pelos estudantes, bem como a realização de um trabalho mais completo pelos professores. Das conclusões da pesquisa, notamos que a maioria das obras apresentam conceitos de pensadores helenísticos, mas, com poucas exceções, não deram atenção à questão do uso de fragmentos de textos.

Palavras-chave: livros didáticos; filosofia helenística; fragmentos de textos.
\end{abstract}

\begin{abstract}
The article presents a comparative analysis of the books of philosophy of high school offered by the National Program of the Didactic Book (PNLD) 2015 to the public network of Brazilian education, specifically the themes and questions around the Hellenistic philosophers. For this purpose, we observe the concepts and the use of fragments of philosophical texts that collaborate to the understanding of the subjects by the students, as well as the accomplishment of a more complete work by the teachers. From the conclusions of the research, we noticed that most of the works present concepts of Hellenistic thinkers, but, with few exceptions, it did not pay attention to the use of fragments of texts.
\end{abstract}

Keywords: textbooks; Hellenistic philosophy; fragments of texts.

\section{Introdução}

O presente artigo $^{3}$ analisa como as chamadas filosofias helenísticas são abordadas nos

\footnotetext{
${ }^{1}$ Mestrando em Filosofia pela Universidade Federal do Ceará (PROF-FILO). Professor de Filosofia na Educação Básica do Ceará (SEDUC-CE) e na Faculdade Ratio. E-mail: alexsousa.filosofia@gmail.com

${ }^{2}$ Doutor em Filosofia pela Pontifícia Universidade Antonianum - Roma . Professor do PROF-FILO, núcleo UFC. Email: jcdafilosofia@hotmail.com
} 
livros didáticos de filosofia da educação básica. Delimitamos, dentro da diversidade de obras existentes, os livros fornecidos pelo MEC às instituições públicas brasileiras para os três anos do Ensino médio, especificamente os selecionados no Programa Nacional do Livro Didático (PNLD) do ano de 2015.

Ao todo, foram cinco obras aprovadas no PNLD 2015, todas produzidas por pesquisadores e professores brasileiros ${ }^{4}$. Filosofando - Introdução à Filosofia tem como autoras Maria Lúcia de Arruda e Aranha e Maria Helena Pires Martins e foi publicado pela editora moderna (5 $5^{\mathrm{a}}$ ed., 2013). Filosofia: Experiência do Pensamento é de autoria de Sílvio Gallo, publicado pela editora Scipione (1 ${ }^{a}$ ed., 2013). Filosofia: Por uma Inteligência da Complexidade tem Celito Meier como autor, sendo publicado pela Pax Editora (2 ed., 2013). Fundamentos de Filosofia foi escrito por Gilberto Cotrim e Mirna Fernandes e publicado pela Editora Saraiva (2a ed., 2013). Por fim, Iniciação à Filosofia, escrito por Marilena Chauí e

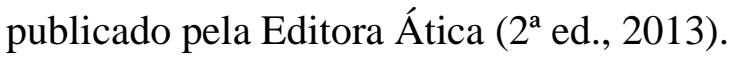

Dos diversos pontos a serem analisados, observamos como cada livro trabalha os conceitos dos pensadores helenísticos (epicurismo, estoicismo, cinismo e ceticismo) ${ }^{5}$ e o estímulo à leitura das obras dos filósofos através de fragmentos de textos. Para isso, lançamos mão do livro do estudante e do livro do professor, importante fonte para presente estudo.

Mas o que entendemos por filosofia helenística? Movimentos filosóficos, muitos constituídos em escolas, como o Epicurismo e o Estoicismo, que tiveram seu surgimento e desenvolvimento durante o período histórico chamado helenismo, em que a domínio macedônio sobre a Grécia dá fim a experiência democrática, especialmente em Atenas, e fomenta o entrelaçamento entre a cultura grega e a oriental, decorrente das conquistas de Alexandre e sua forma de administrar os territórios conquistados.

Assim, o objetivo central da pesquisa é observar que atenção é dada às correntes filosóficas nos livros que desenvolveram um modo de lidar consigo mesmo e com o mundo de modo singular, que na atualidade são extremamente necessários.

A coerção do mundo contemporâneo e capitalista se dá, principalmente, pelo estímulo

\footnotetext{
${ }^{3}$ O presente trabalho foi requisito para aprovação na disciplina Tópicos Específicos de Filosofia e o seu Ensino no Mestrado Profissional em Filosofia da Universidade Federal do Ceará (UFC), que tinha como tema/objeto central a análise das correntes filosóficas helenísticas, especialmente o Epicurismo.

${ }^{4}$ A ordem de apresentação dos livros segue a mesma do Guia de livros didáticos PNLD 2015.

${ }^{5} \mathrm{Um}$ dos objetivos da presente pesquisa era analisar recursos extras, que chamamos aqui de audiovisuais, fornecidos pelos autores aos professores e, principalmente, aos estudantes, como fotos, imagens, músicas e obras de arte que colaborem com o aprendizado dos discentes. Entretanto, não apresentamos as conclusões em decorrência da apresentação das imagens, que precisão de autorização, além de extrapolar a quantidade de páginas permitidas. Contudo, nas considerações finais, tecemos algumas conclusões a respeito desse ponto que deixamos de apresentar neste trabalho.
} 
ao consumo que fomenta um modo de vida ideal, que se não alcançado, alimenta o surgimento de doenças como anorexia, estresse e depressão, bem como uma limitação da liberdade dos sujeitos, já que o mercado em parceria com a publicidade estimula a criação de verdades ilusórias e subjetividades que tomem essas ilusões como certas.

Com isso, compreendemos que as filosofias/modos de vida helenísticos, despontam como possibilidades de criação de vidas autônomas, livres e singulares, fundamental para o ser humano e para a democracia.

\section{Os livros didáticos de filosofia para o ensino médio.}

\section{A filosofia e a Grécia sob o domínio de Alexandre.}

Todas as obras analisadas relacionam o pensamento filosófico helenístico ao momento de domínio da Grécia pelos macedônios, especialmente sob o comando de Alexandre Magno, frisando a mudança dos contextos históricos que passava do espaço político grego para o mundo comandado por uma só pessoa, em que os filósofos passaram de cidadãos a súditos.

Mirna Fernandes e Gilberto Cotrim (2013), bem como Marilena Chaú (2013), ressaltam o contato que os gregos tiveram com a cultura oriental no governo de Alexandre, que possibilitou uma orientação da Filosofia. Chauí ressalta o papel que essas filosofias tiveram sobre o pensamento cristão, assim como fez Silvio Gallo (2013), quando trata do estoicismo.

\section{O pensamento helenístico nos livros didáticos.}

\section{Epicurismo}

A filosofia proposta por Epicuro é apresentada em todas as obras analisadas. Com exceção de Marilena Chauí, que apresenta as características gerais da filosofia helenística sem expor em detalhes o pensamento de cada corrente ${ }^{6}$, todos os outros mostram problemas, bem como os conceitos e os modos de vida criados por cada um.

A afirmação do prazer, possibilitado pelo uso da razão, como fonte da felicidade e a

\footnotetext{
${ }^{6}$ Esse detalhe na obra de Chauí se dará em todas as outras correntes analisadas, com exceção do problema da morte para os estoicos, que será trabalhado pela autora no capítulo intitulado ética, e apresentaremos na parte devida.
} 
ataraxia - o estado de imperturbabilidade da alma -, resultado desse uso dos prazeres e condição de possiblidade para a felicidade, são teses consideradas por todos os autores.

Maria Lúcia e Maria Helena (2013); Gallo (2013); Mirna e Cotrim (2013) trabalham a influência do atomismo de Demócrito no pensamento de Epicuro, bem como suas consequências na percepção sobre a morte, problema que, para o filósofo helênico, as pessoas não deveriam ter, pois o corpo e a alma são feitos de átomos, que no momento da morte se desagregam e passam a constituir outra coisa.

Assim, pensar na morte, que geralmente é pensar naquilo que vem depois dela, é um problema desnecessário, pois o fim da vida é somente o ato de desagregação dos átomos. (ARANHA, MARTINS, GALLO, COTRIM, FERNANDES, 2013).

Os autores, apresentando a apropriação da filosofia de Demócrito acerca da constituição do mundo (átomos) em Epicuro, e sua compreensão sobre a morte, afirmam que as superstições, mitos e crenças nos levam a temer algo que não precisa ser temido. Esse pavor nos leva a sofrer por antecipação, nos afastando da ataraxia. (ARANHA, MARTINS, GALLO, COTRIM, FERNANDES, 2013).

Epicuro afirma a existência de um quádruplo remédio (Tetraphármacon) que leva os seres humanos a serem felizes. Esse 'medicamento' é apresentado por Maria Lúcia e Maria Helena (2013) e Gallo (2013). São quatro pontos a se observar: não temer dos deuses; saber que a morte não nos traz riscos; ver que o prazer, se bem entendido, proporciona o bem/felicidade; ser ciente que a dor é suportável. (ARANHA, MARTINS, GALLO, 2013).

Alguns autores, como observado, apresentaram teses em comum do pensamento epicurista em suas obras. Contudo, cada um deu foco particular a questões específicas. Maria Lúcia e Maria Helena ressaltam o uso do termo hedonismo no sentido do gozo dos prazeres com moderação. Elas frisam a questão do materialismo presente em Epicuro decorrente do atomismo de Demócrito. Eles levantam a hipótese de que esse materialismo, bem como a visão de Epicuro sobre as divindades, seriam as causas pelo rechaço ao epicurismo e da má compreensão de sua ética.

Sílvio Gallo (2013) pontua a diferença entre o estoicismo e o epicurismo no que diz respeito à conquista da ataraxia, já que Epicuro afirmava ser o prazer racional a fonte da saúde e da felicidade, enquanto os estoicos defendiam o exercício da virtude e a recusa ao prazer. Gallo também ressalta a importância da amizade para os epicuristas, vista como um dos prazeres racionais, presente na comunidade que era o Jardim, local onde se reuniam. $\mathrm{O}$ autor mostra ainda a influência do Epicurismo no pensamento filosófico posterior, citando 
Diógenes de Enoanda, Tito Lucrécio Lívio - que influenciaria Michel de Montaigne-, Nietzsche, Michel Foucault e Michel Onfray, este último propondo uma filosofia chamada materialismo hedonista.

Celito Meier (2014) também trata a questão da amizade presente naqueles que frequentavam o jardim de Epicuro, e sua máxima de que todos podem filosofar. $\mathrm{O}$ autor detalha uma questão levantada por Cotrim e Mirna (2013), a apresentação das diversos prazeres, que podem ser não naturais e não necessários (luxo e riqueza), naturais e não necessários (dormir em lençóis de seda) e os naturais e necessários (comer, beber e dormir), sendo estes últimos aqueles que possibilitam o uso racional do prazer, pois evitam que os homens vivam uma 'vida devassa' e alienem sua liberdade.

Gilberto Cotrim e Mirna Fernandes (2013) organizam o pensamento de Epicuro num tópico intitulado como viver para ser feliz, apresentando sua filosofia como um passo a passo para ser feliz. Desse modo, eles apresentam três subtópicos, compreendidos como os três passos para alcançar a ataraxia: eliminar certas crenças; eliminar ou moderar os desejos; agir com prudência racional. Os autores afirmam que a filosofia epicurista é sensualista e que a prudência racional leva o ser humano a uma autarquia que é a condição para se chegar a ataraxia.

\section{Estoicismo}

Todas as obras analisadas apresentam a filosofia estoica. Entretanto, muitos dos autores usam termos/conceitos diferentes para expor problemas em comum ${ }^{7}$.

Com exceção de Marilena Chauí ${ }^{8}$ (2014), todos explicam a razão do nome estoicismo, que decorre do termo stoá, pórtico em Grego, lugar onde os membros da corrente filosófica se reunião, pois o seu fundador Zenão de Cício, por não ser cidadão grego, não teve direito a obter terras em Atenas.

Como no epicurismo, os estoicos buscavam a paz interior, a ataraxia. Todos os autores afirmam que esse é o meio para ser feliz. Contudo, com exceção de Gallo (2013), ressaltam que a apatia - eliminação das paixões -, é o meio para se chegar ao estado de paz interior (ARANHA, MARTINS, COTRIM, FERNANDES, 2013. MEIER, 2014).

\footnotetext{
${ }^{7} \mathrm{O}$ uso de termos diferentes para um conceito criado por um filósofo pode ser resolvido com um trabalho analítico e etimológico das obras originais. Contudo, nosso intuito aqui é a análise dos problemas e conceitos apresentados nas obras de filosofia para o ensino médio, e não uma comparação destes com as obras dos filósofos.

${ }^{8}$ Ver nota 3. O mesmo se repeti em torno do Estoicismo, com exceção da questão da morte.
} 
Todos os autores mostram que, para os estoicos, há uma razão na natureza que nos impossibilita ver nossa vontade como aquilo que decide os acontecimentos. Todavia, não afirmam que a vontade esteja anulada, mas que sua realização não se dá sem a existência de uma ordem maior que ela. (ARANHA, MARTINS, COTRIM, FERNANDES, GALLO, 2013. MEIER, 2014).

Sílvio Gallo (2013) usa o termo acontecimento; Maria Lúcia e Maria Helena (2013), bem como Cotrim e Mirna (2013), usam o termo Deus e destino, além de ordem cósmica; Celito Meier (2014) usa razão universal e inteligência.

Enfim, com diferentes termos, estes autores mostram que para os estoicos havia uma racionalidade na natureza que ditava a ordem das coisas. Cabia aos seres humanos aceitar sua existência, o que evitariam o sofrimento, já que entenderiam que os fatos existentes no mundo não estão sob seu comando. É preciso então, amar o acontecimento/destino/ordem cósmica/natureza/razão universal/inteligência.

No Filosofando, Maria Lúcia e Maria Helena citam as semelhanças entre o estoicismo e o epicurismo: a defesa da materialidade, a negação de uma transcendência do divino e a visão da filosofia como modo de vida. Porém afirmar que a diferença central entre eles são as posições em relação aos prazeres, já que os estoicos os veem como aquilo que tira a paz interior, fonte da felicidade. Diferente dos outros, elas usam o termo panteísmo para falar da razão divina que está em tudo.

No Filosofia: Experiência do Pensamento, Sílvio Gallo afirma que o pensamento cínico teve grande influência sobre o estoicismo, mas com um rigor diferenciado, menor. Afirma também que os estoicos tinham um sistema filosófico contendo uma física, uma lógica e uma ética, além de ser a corrente filosófica que mais durou no mundo antigo, com três períodos: o antigo, o médio e o eclético ou imperial.

Gallo (2013) ressalta que para os estoicos é necessário se preparar alcançar o estado de imperturbabilidade da alma, o que se daria através de exercícios espirituais, como a meditação e a escrita. O autor, citando Epiteto, trata dos conceitos de liberdade e servidão, colocando aquele como o poder de controlar aquilo que depende de nós, o pensamento e a vontade, e que tentar controlar o que não depende de nós, como as riquezas e as honrarias, é o início da servidão.

Gallo (2013) lembra que o estoicismo teve uma influência significativa sobre o cristianismo, principalmente na resignação que surge da posição dos estoicos sobre a conformação e o acontecimento. 
No Filosofia: Por uma Inteligência da Complexidade, Celito Meier ressalta que a ética estoica é fortemente marcada pelo fatalismo e determinismo, por isso, devemos ser indiferentes frente aos fatos que ocorrem no nosso dia a dia. Ele ressalta que o modo de vida estoico fomenta uma vida virtuosa, sendo as virtudes fundamentais a inteligência, a coragem e a justiça. $\mathrm{O}$ autor também ressalta que o sábio é aquele que sabe superar os efeitos das paixões, pois não se deixa apreender pelos objetos exteriores a ele.

Em Fundamentos de Filosofia, Gilberto Cotrim e Mirna Fernandes, como no trato com o epicurismo, apresentam a parte sobre os estoicos em subtópicos que, se seguidos, proporciona aquele que lê uma ideia do sistema filosófico e a melhor maneira de viver.

Para compreender a ordem cósmica é necessário compreender que há dois princípios na natureza, um passivo (matéria) e um ativo (logos/providência) que está em tudo, tornando tudo o que ocorre necessário e pré-determinado. Eles ressaltam nessa realidade, que o ser humano deve aproveitar as oportunidades que surgem na ordem cósmica, pois são nelas que a vontade pode se realizar, possibilitando a verdadeira liberdade (COTRIM, FERNANDES, 2013).

Compreender isso é, então, o necessário para ser feliz, devendo o ser humano amar o que venha a ocorrer, amar o destino. Os autores afirmam que esse amor é o amor fati, seguindo o logos que é bom. Assim, ser feliz é compreender o funcionamento do universo, o que também proporciona ao ser humano ser dono de si mesmo (COTRIM, FERNANDES, 2013).

No livro Iniciação à Filosofia, Marilena Chauí, no fim do capítulo sobre a liberdade, “o objeto central dos estudos da ética” (CHAUÍ, 2014, P. 277), realiza uma reflexão sobre a "Vida e a morte", afirmando que elas são "acontecimentos simbólicos, são significações, [que] possuem sentido e fazem sentido".

Citando o filósofo estoico Sêneca, Chauí (2014) afirma que a vida e a morte não são acontecimentos unicamente biológicos, mas são também simbólicos. Assim, nesta compreensão do ser humano, só poderíamos saber quem somos após a morte, pois não somos somente vida, mas também morte que "completa o que somos dizendo o fomos". Ela nos mostra que, segundo os estoicos, só podemos saber se alguém foi feliz ou infeliz depois da morte.

\section{Cinismo}


Diferente do epicurismo e do estoicismo, o cinismo é apresentado somente por três autores, Maria Lúcia e Maria Helena (2013), Sílvio Gallo (2013) e Cotrim e Mirna Fernandes (2013). Ambos afirmam a figura de Diógenes de Sinope como o maior representante, não ocorrendo o mesmo quanto à data de nascimento do mesmo, pois cada um apresenta uma diferente $^{9}$. Todos os autores mostram o modo de cínico através de fatos vivenciados pelos seus adeptos, em especial Diógenes.

Maria Lúcia e Maria Helena (2014) mostram como o termo cinismo é hoje compreendido de modo pejorativo, não condizendo com o sentido dado pelos filósofos dessa escola na antiguidade. Elas apresentam duas hipóteses para a origem do termo cinismo: uma relacionada ao termo Kyon (grego) e Cion (latim), ambos significando cão; outra se referindo ao ginásio de Cinosargos, lugar onde se iniciou a doutrina com Antístenes (445-365 a.C.), fundador do cinismo.

As autoras ressaltam a forma dos filósofos cínicos viverem na simplicidade, sem pudores, propondo um novo modo de vida que afrontava com os costumes, considerando as riquezas, as honras e convenções futilidades (ARANHA, MARTINS, 2014).

Sílvio Gallo (2013) mostra que o cinismo foi fundado por Antístenes, mas que "foi com Diógenes de Sinope [...] que essa filosofia ganhou mais expressão e popularidade" (GALLO, 2013, p.156). O autor afirma que a principal lição deixada pelo cinismo é a de "levar as últimas consequências a ideia de uma vida orientada pela virtude", onde "suas próprias vidas eram um tratado de ética".

Gallo (2013) compara em dois momentos, os cínicos a Sócrates. Primeiro no fato de não terem deixado nada escrito, e segundo o método dialógico, que se diferenciava do de Sócrates, pois os cínicos usavam do humor e não a ironia como ferramenta de conhecimento. Apresentando o modo de vida cínico, o autor cita episódios da vida de Diógenes, como o encontro dele com Alexandro Magno, onde o filósofo afirma que o mesmo não poderia dar nada que não tinha, no caso o Sol; o caso onde ele joga um galo sem penas no meio do encontro de Platão com seus discípulos, já que este tinha afirmado que o ser humano era como um galo depenado; e o caso da cuia que Diógenes dá ao primeiro que passa por ter visto uma criança bebendo água com as mãos.

Mirna Fernandes e Gilberto (2013) Cotrim afirmam que o termo cinismo vem do grego Kynos (Cão), e significa 'como um cão', se referindo a sujeitos que se propuseram a

\footnotetext{
${ }^{9}$ Os autores colocaram as datas de nascimento de morte de Diógenes de Sinope do seguinte modo: Maria Lúcia e Maria Helena (c. 400-323 a.C.); Sílvio Gallo (412/103 a.C. - 324/324 A.C); Mirna Fernandes e Gilberto Cotrim (c. 423-327 a.C.).
} 
viver como cães, sem "propriedade ou conforto". Os autores afirmam o cinismo, citando especificamente Diógenes de Sinope, radicalizou duas teses socráticas, o conhecer a si mesmo e o desprezo à obtenção de bens materiais para se viver.

Mirna e Cotrim (2013) ressaltam que Diógenes fora chamado de “"Sócrates demente', ou o 'Sócrates louco', pois questionava os valores e as convenções de forma radical e procurava levar uma vida estritamente conforme os princípios que considerava moralmente corretos” (MIRNA, COTRIM, 2013, p. 231).

\section{Ceticismo/ Pirronismo}

Como no cinismo, as questões do pirronismo foram apresentadas em três livros. Maria Lúcia e Maria Helena (2013) citam que o filósofo Pirro de Élida (360-270 a.C.) foi seu maior representante e que teria conhecido diversos povos e valores quando acompanhou Alexandre Magno. Por isso, Pirro teria tido a possibilidade de confrontar as diversas convicções existentes, afirmando que ninguém poderia discernir o verdadeiro do falso. Assim, a melhor maneira de agir no mundo (caráter ético) seria suspendendo o juízo, por que "aqueles que se prendem a verdades indiscutíveis estão fadados à infelicidade, já que tudo é incerto e fugaz" (ARANHA e MARTINS, 2013, p. 86.).

Celito Meier (2014) também afirma que Pirro (360-270 a.C.) é o fundador do ceticismo, corrente filosófica que criou uma postura diferenciada perante a vida, pois partiam de uma "descrença generalizada ou dúvida sobre tudo".

O autor mostra que os céticos viam o conhecimento como algo sempre relativo, já que surge de uma interpretação subjetiva dos homens. Com isso, todo conhecimento é resultado da percepção de alguém, podendo ser diferente de uma pessoa para outra (MEIER, 2014).

Celito (2014) afirmam então que, para os céticos, "não parece ser possível um conhecimento seguro de como o mundo é precisamente" (MEIER, 2014, Pag. 151). Diante dessa realidade, o caminho mais seguro para se viver seria suspender o juízo, evitando decidir entre o certo e o errado.

Essa postura se mostra como um combate ao dogmatismo que, segundo Celito (2014), "traz grandes contribuições para a vida democrática, uma vez que as diferenças são respeitas e defendidas". Para os céticos, a suspensão do juízo é o que possibilita a imperturbabilidade da alma (ataraxia), pois buscar uma verdade, um conhecimento seguro e definitivo que nunca se achará, é a fonte da perturbação dos homens. 
Com isso, o autor ressalta a comparação entre o pensamento cético e o sofistico, devido a suas posições sobre a verdade, mas observa que os sofistas orientam os homens a seguir uma determinada ideia (MEIER, 2014).

Celito conclui que a ataraxia cética se dá pela suspensão do juízo, caminho para a felicidade, que evita a influência das crenças e do fanatismo. Ele complementa:

podemos ver no ceticismo uma maneira de viver, um esforço constante para adquirir a independência maior possível dos acontecimentos do mundo, de fazer a felicidade depender o mesmo possível dos eventos externos, sujeitos aos acasos da vida. Isso não significa indiferença, mas, sim, independência. (MEIER, 2014, p. 152)

Por fim, Mirna Fernandes e Gilberto Cotrim (2013) tratam do pirronismo, no tópico nomeado Pirronismo: a suspensão do juízo. Eles mostram que para os céticos nenhum conhecimento é seguro e, por isso, creditar confiança em algo fixo e imutável seria o caminho para a infelicidade e falta de paz. Com isso, os autores afirmam que o pirronismo é um ceticismo, pois chegar a uma verdade absoluta é impossível. É impossível, por isso, a construção de conhecimento.

\section{Fragmentos de textos filosóficos nos livros didáticos do ensino médio.}

O contato dos discentes do ensino médio com as obras originais dos filósofos é momento importante no processo de aprendizado da filosofia pelos estudantes. É o momento do contato direto com os filósofos. Contudo, mesmo todos os autores trabalhando com textos de filósofos em diversas partes de suas obras, não foram todos que dedicaram um espaço específico para se trabalhar textos dos filósofos helenísticos.

No Filosofando - Introdução à Filosofia, Maria Lúcia e Maria Helena trabalham fragmentos dentro da apresentação do pensamento de um filósofo ou no fim do capítulo (Leitura complementar), ocupando toda uma página e acompanhados de questões.

Os dois fragmentos presentes na obra foram extraídos da Carta sobre a felicidade [a Meneceu] de Epicuro, sendo o primeiro um incentivo a que todos filosofem o mais cedo possível, não esperando à velhice para filosofar. O segundo fala do prazer para Epicuro. Os dois fragmentos foram bem escolhidos e colocados em lugares adequados, não deslocados do texto. Todavia, não há mais nenhuma referência, inclusive no tópico leitura complementar (ARANHA, MARTINS, 2013). 
No Filosofia: Experiência do Pensamento, Sílvio Gallo trabalha os fragmentos de textos filosóficos dentro de cada capítulo e no final, sempre colocando dois grandes fragmentos (Trabalhando com textos), seguidos de questões que os problematizam.

No capítulo sobre ética, onde apresenta os helenísticos, há uma diversidade de micro fragmentos. Os dois primeiros são citações retidas do livro de Léonce Paquet sobre Diógenes de Sinope. No primeiro este diz que não existem astros errantes, mas homens que erram. O segundo ironiza a atitude de uma mulher que iria fazer um tratamento de beleza (GALLO, 2013).

O terceiro fragmento é extraído do livro Manual de Epiteto, em que fala da relação entre a liberdade e a felicidade. O quarto foi retirado das Meditações de Marco Aurélio, onde mostra dois motivos para conformar-se diante do que foi prescrito para cada um, pois desse modo os seres humanos colaborariam com o bom andamento do conjunto (GALLO, 2013).

O quinto é do já citado livro de Epiteto, que fala do acontecimento como a possibilidade de liberdade. O sexto e sétimo são de Epicuro e foram extraídos de uma antologia de textos (Coleção os pensadores). O primeiro sobre o que é o prazer, o segundo sobre a morte (GALLO, 2013).

O oitavo e último fragmento é uma citação do livro A gaia Ciência de Nietzsche, no qual faz um agradecimento por ter entrado em contato com os textos de Epicuro. Ao fim do capítulo, na parte trabalhando com textos, há dois grandes fragmentos. O primeiro é da Carta sobre a felicidade de Epicuro, em que foca na questão da felicidade (GALLO, 2013).

O outro é do Sobre a brevidade da vida de Sêneca, na parte que trata justamente do tema do livro. Todos os fragmentos escolhidos por Silvio Gallo foram adequados e não estão deslocados das temáticas propostas, podendo o professor fazer bom uso e possibilitar ao aluno um aprofundamento dos temas trabalhados e o conhecimento dos filósofos (GALLO, 2013).

No Filosofia: Por uma Inteligência da Complexidade, Celito Meier também trabalha com fragmentos no meio e o fim de cada parte, principalmente na parte Textos filosóficos, problematizações e atividades, onde coloca grandes fragmentos.

Entretanto, Celito (2014) diferencia-se de Gallo (2013), pois não espera o fim do capítulo para colocar esses maiores, colocando-os logo após o pensamento analisado. Ele inicia o capítulo sobre os helenistas falando de Epicuro. Não coloca nenhum micro fragmento de texto, mas ao fim deste tópico fornece um fragmento de sete parágrafos da Carta sobre a felicidade de Epicuro.

No tópico sobre o Estoicismo, Celito (2014) coloca um micro fragmento do Sobre a 
brevidade da vida de Sêneca, orientando os homens a viverem o presente e não esperar a velhice para se destinar à meditação. Mas ao fim deste tópico, Celito coloca um grande fragmento deste mesmo texto, que trata do determinismo, fatalismo, liberdade, indiferença e felicidade.

Quando fala dos céticos, Celito (2014) não disponibiliza nenhum fragmento. No geral, os fragmentos escolhidos pelo autor foram bem adequados, pois está diretamente relacionado aos temas e problemas propostos no capítulo, o que possibilita ao professor do ensino médio desenvolver um interessante trabalho de aprofundamento.

No livro Fundamentos de Filosofia, Gilberto Cotrim e Mirna Fernandes (2013) trabalham somente micro fragmentos dentro dos capítulos. Nas duas partes em que eles trabalham a filosofia helenística somente no primeiro, Como viver para ser feliz, são trabalhados micro fragmentos.

Quando falam sobre a percepção epicurista acerca do medo da morte, os autores citam Epicuro na Carta sobre felicidade [a Meneceu], mostrando que não podemos saber o que é a morte, pois quando estamos vivos não a conhecemos, e quando estamos mortos já não podemos mais saber (COTRIM, FERNANDES, 2013).

Quando apresentam o estoicismo, Mirna e Cotrim (2014) citam Epiteto, retirado do livro A filosofia e a felicidade de Philippe Van Den Bosch, falando da dominação dos desejos e controle dos pensamentos, no qual afirmam que não é o que fazem com alguém a causa dos sentimentos negativos, mas a opinião da pessoa que sofre o ato, pois ela deve dominar as paixões como a ira, e não se deixar levar pela "imaginação".

Mesmo que Mirna e Cotrim (2013) trabalhem outras questões nos capítulo em que apresenta a filosofia helenista, vemos que poderiam adequar algumas partes do livro para incluir fragmentos maiores, possibilitando o professor trabalhar de forma mais ampla a leitura dos textos dos filósofos.

Por fim, na obra Iniciação à Filosofia, Marilena Chauí trabalha com fragmentos de textos filosóficos dentro do próprio capítulo, no boxe intitulado Diálogos filosóficos. Todavia, em nenhum momento há fragmento de textos de filósofos helenísticos aqui trabalhados.

\section{Considerações finais}

Os professores de filosofia do ensino médio, bem como os autores das obras analisadas, possuem visões diferenciadas em torno da verdade e da concepção de filosofia. 
Cada um fala de "lugar" diferente. Por esse motivo, sempre faltará algo na obra ou não satisfará a necessidade de um professor, ainda mais tratando de uma disciplina com uma história tão longa e com diferentes modos de existir (filosofias).

Propomos investigar como os livros didáticos oferecidos às escolas públicas brasileiras apresentam o pensamento dos filósofos helenísticos, principalmente, o epicurismo, o estoicismo, o cinismo e o ceticismo. Por isso, demos atenção à insuficiência dos pontos analisados, o mesmo não ocorre necessariamente nas demais partes dos livros, já que analisamos correntes filosóficas que historicamente foram vistas como secundárias e como pouco influentes na história da filosofia.

Todos os livros apresentam questões levantadas pelos filósofos helenistas, mas os livros Filosofando e Fundamentos de Filosofia são os únicos que trabalham as quatro correntes filosóficas.

O livro Iniciação a Filosofia é o que menos fornece detalhes sobre as filosofias helenísticas, apresentando poucos conceitos, o que impossibilita o professor que aderiu a referida obra, um trabalho aprofundado com o mesmo em suas aulas de filosofia. Essa ausência não ocorre nas outras obras, pois contemplam seus livros com uma diversidade de conceitos e questões. Contudo, nos livros Fundamentos da Filosofia e o Filosofia: uma experiência do pensamento foi dada atenção diferenciada às filosofias helenísticas.

Todos os autores, no livro do professor, afirmam a importância do uso de textos filosóficos nas aulas de filosofia. Entretanto, somente Celito Meier (2014) e Sílvio Gallo (2013) diferenciam o olhar sobre a questão.

Mesmo que os outros autores tenham colocado citações de obras dos filósofos ou de comentadores, é notável que o trabalho com textos filosóficos, especialmente os helenísticos, não receberam a devida atenção. Uma possibilidade dos autores solucionarem essa questão seria o uso da tecnologia, como aplicativos ou sites que forneçam vídeos, livros em pdf ou qualquer outro recurso, como imagens e músicas.

Neste contexto, concordamos com Sílvio Gallo quando diz:

A filosofia foi produzida e se desenvolveu segundo a lógica do polo da escrita; portanto, sua principal forma de codificação é o texto. [...] Daí a importância do trabalho com textos filosóficos que aprendemos filosofia, e assim não podemos dispensar essa atividade no Ensino Médio. (GALLO, 2014, p. 317)

Um dos objetivos da presente pesquisa era analisar recursos extras, que chamamos 
aqui de audiovisuais, fornecidos pelos autores aos professores e, principalmente, aos estudantes, como fotos, imagens, músicas e obras de arte, que colaborem com o aprendizado dos discentes. Por motivos burocráticos não foi possível apresentá-las aqui. Entretanto, segue algumas considerações a respeito desse ponto que consideramos de importante num livro didático para o ensino médio.

O livro de Sílvio Gallo (2013) mostrou grande preocupação com os recursos audiovisuais, secundários frente aos conteúdos mais importantes, já que o livro é utilizado por estudantes que, em sua grade maioria, não possuem o hábito da leitura. Com isso, se bem utilizados os recursos audiovisuais fomentam a empatia do discente às teorias dos filósofos.

O livro de Celito Meier (2014), mesmo bem estruturado, necessita de uma atenção aos recursos audiovisuais, pois as ilustrações não têm um objetivo claro, nem problematizam o conteúdo estudado. Consideramos que neste caso o problema possa ser também editorial, já que o autor dedica uma atenção as correntes helenísticas.

A obra de Mirna Fernandes e Gilberto Cotrim (2013) demonstra uma preocupação com as questões audiovisuais, porém poderiam ser mais articulados com o conteúdo, onde algumas imagens poderiam substituídas por outras mais adequadas a problematização.

Já o Filosofando, livro de Maria Lúcia e Maria Helena, mesmo sendo um livro bem ilustrado, precisa de imagens e questões que possam realmente ampliar a possibilidade de compreensão do tema trabalhado.

O livro de Marilena Chauí (2014) é bem organizado e ilustrado, mas por dar pouco espaço ao pensamento helenístico, tanto os conceitos, como as ilustrações, ficaram limitados.

Em geral, a filosofia helenística foi trabalhada por todos os autores. Nossa hipótese sobre os fatores que os levaram a darem maior ou menor atenção as diferentes questões levantadas é a forma como cada um pensa e trabalha o ensino de filosofia; um rigor conceitual; história da filosofia; temas de filosofia; método de ensino de filosofia; etc.

Quanto à ilustração das obras, bem como as problematizações de questões extras, os autores devem revê-las e observar nas próximas edições, já que elas proporcionam uma maior compreensão do conteúdo por parte dos discentes, assim como auxiliam os professores na prática pedagógica.

Por fim, pontuamos que a maioria dos autores precisa observar com maior atenção o trabalho com o pensamento helenístico, importante para a atualidade, já que as diversas correntes e modos de vida desenvolvidos pelos filósofos neste período são modelos de 
cuidado de $\mathrm{si}^{10}$ que possibilitam aos seres humanos uma atitude de liberdade e resistência frente à vida.

Além disso, são filosofias que fomentam a empatia, princípio importante para a construção e fortalecimento de uma democracia, já que neste modelo de governo todos os cidadãos têm direito a ter direitos, e ensinar os sujeitos a olhar o outro com atenção, defendendo a dignidade e a vida é educar pessoas para uma sociedade justa. Por isso, educar pessoas que vejam a postura ética dos filósofos helenistas como modelos de vida é educar para todos.

\section{Referências bibliográficas}

ARANHA, Maria Lúcia de Arruda e MARTINS, Maria Helena Pires. Filosofando: introdução à filosofia. $5^{\mathrm{a}}$ ed. São Paulo: Ed. Moderna, 2013.

GALLO, Sílvio. Filosofia: experiência do pensamento. $1^{a}$ ed. São Paulo: Scipione, 2013.

CHAUÍ, Marilena. Iniciação à Filosofia. 2a ed. São Paulo: Ed. Ática, 2014.

COTRIM, Gilberto e FERNANDES, Mirna. Fundamentos de Filosofia. $2^{\text {a }}$ ed. São Paulo: Ed. Saraiva, 2013.

MEIER, Celito. Filosofia: por uma inteligência da complexidade. $2^{a}$ ed. Belo Horizonte: Ed. Pax, 2014.

Ministério da Educação, Secretaria de Educação Básica. Guia de livros didáticos: PNLD 2015: filosofia: ensino médio. Brasília, 2014. 52p.

RATIER, Rodrigo e SOARES, Wellington. Livro didático: como usá-lo com equilíbrio. Nova escola. Fortaleza, 09/07/2017. Disponível em: https://novaescola.org.br/conteudo/1731/livro-didatico-como-usa-lo-com-equilibrio.

\footnotetext{
${ }^{10}$ O filósofo francês Michel Foucault (1926-1984), em seus últimos escritos, retoma o conceito 'Cuidado de Si' que, para ele, pode ser visto como um fenômeno cultural que existiu no mundo antigo, mas que não recebeu a devida atenção pelos historiadores da filosofia. Desse modo, o presente trabalho foi influenciado pela leitura de Foucault em torno da antiguidade grega e romana. Para uma maior compreensão dessa leitura de Foucault e do Cuidado de Si, ver o curso "A hermenêutica do Sujeito" (Ed. Martins Fontes).
} 